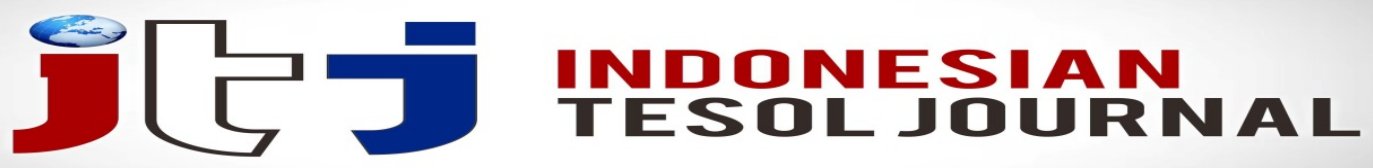

e-ISSN: 2622-5441(Online) Journal homepage: https://ejournal.iainpalopo.ac.id/index.php/ITJ/index

\title{
Student and teacher perceptions of student motivation among Korean university English as a Second Language (ESL) students
}

\author{
Luke Oliver Henry Allum \\ Hanyang University, South Korea
}

Abstract: This paper analyses the differences between what teachers say motivates their students and what students say motivate them at a South Korean university. Using motivational constructs developed by Bandura and Maslow in previous motivation studies, it was determined that both teachers and students think teacher characteristics to be the most important variable motivating students, even more important than the student's own intrinsic motivation. However, there was no agreement between students and teachers on what this looks like specifically in the classroom: teachers prefer to stimulate students' creative thinking and to help students solve real-world problems, whereas students prefer to learn with digital media, presentations, and quizzes. Teachers and students both believe students to be highly intrinsically motivated, with the caveat that some students come to class lacking intrinsic motivation. This paper is significant in that students report teacher characteristics and instructional methodologies to be of more importance than a student's intrinsic motivation. This paper reveals that teachers consistently over-rate the importance of teacher characteristics and methodologies on student motivation.

Keywords: ESL, extrinsic; intrinsic; Korea; mastery; motivation; self-efficacy; social goals; student motivation

\section{INTRODUCTION}

This research project examines what motivates students in their studies at a Korean university. The paper uses models of human motivation developed by Maslow (1954) as well as Bandura (1993) in order to understand the motivation of Korean university students studying in native English programs at a Korean university. In all, the paper assesses eight separate motivational construct categories and compares student reports of motivation with teacher perception of student motivation. It has been well documented that student motivation declines throughout the school years (Wigfield et al., 1998), and a study on American university students found that students were far more likely to attribute their motivation to factors beyond the teacher's control (Gorham and Millette, 1997); however, there is less literature on student motivation at university level and less still in a Korean-specific ESL context. This research was inspired by a former student's work on student/teacher perceptions of student motivation (Wiesman, 2007) and uses a similar methodological approach. The project aims to shine a light on the factors motivating English as a Second Language (ESL) students in a Korean university and to compare these factors with their teachers' 
beliefs about what motivates their students. A pragmatic, mixed-methods approach is used, with both quantitative and qualitative analyses.

This research attempts to gather information which can be used to present to colleagues and the institution to bring about either a change in institutional policy or an incremental change in teacher and stakeholder judgments about optimised methods of teaching. It is hoped that this can be used to implement further cycles of change on specialised collaboration and presentation days, which occur twice yearly at the beginning of each semester. Research has been undertaken with clear success criteria in mind and in the spirit of Kemmis and Wilkinson's (1998) words: 'We investigate reality in order to change it; we change reality in order to investigate it'.

This research has been conducted on first- and second-year university students whose spoken English language proficiency was determined to range from 'low-intermediate' to 'intermediate-advanced', although the majority of students have 'intermediate-intermediate' level proficiency. Teachers were given a textbook to use to teach students who are pre-assigned classes by their major. The institution does not supervise teaching, and teaching assessment is done by student evaluation, an approach, though incidentally commonplace in South Korea, which has been heavily criticised for seeing teachers as mere performers (Damron, 1995).

This study is an attempt to measure the relative weights of perception on student motivation of students and their teachers. This study used eight different recognised motivational constructs. These are from goal achievement theory (social goals, performance-oriented goals, and mastery-oriented goals), drive theory (intrinsic motivation and extrinsic motivation), as well as self-efficacy and teachers' characteristics and methodologies.

The rationale of this study is to provide an answer to the question 'to what extent do student and teacher perceptions of student motivations align?' Although cultural priorities in Korea are well-studied, such as, in an ESL context, the deprioritising of class dynamics in secondary schools (Guilloteaux, 2013) resulting in a culture of uniformity, the extent to which these perceptions differ is unclear at the university level. Stoking intellectual excitement and student-teacher interpersonal rapport are thought to be teaching universals (Lowman, 1995), but they depend on a complex set of factors including sex, ability, and subject, which also vary by culture. A study of Korean high school students, for example, shows that the institutional emphasis on grammatical knowledge over fluency has important consequences in learning outcomes (Park and Lee, 2006). The degree to which student-teacher perceptions align is, therefore, likely to have highly consequential learning outcomes.

\section{LITERATURE REVIEW}

Human motivation reaches back as far as Maslow (1954), considered one of the founding fathers of human psychology. He stated that human motivation can be divided into five main areas - psychological, safety, love, esteem, and selfactualization (Maslow, 1954) - which fall into 'intrinsic motivation' categories and which are opposite of extrinsic motivation (being motivated to avoid negative 
outcomes). Intrinsic and extrinsic motivation are a type of 'drive theory' and are different from 'goal theories', which emphasise mastery and performance. Different still are 'self-efficacy' and 'control theories', which focus on a student's competence to perform a task, and 'social goals theories', which focus on the degree to which students' motivation is affected by their peers (Eccles and Wigfield, 2002; Bandura, 1993).

It has been well documented that student motivation declines throughout the school years (Wigfield et al., 1998), and this is especially true of student intrinsic motivation as they undergo the five years of high school (Lepper et al., 2005). However, there is less literature on student motivation at the university level, and none could be found on university student motivation in an ESL context. Students at this age are assumed to be more motivated than high school students due to a higher level of maturity and the free choice associated with attending university and their preferred subject.

In a study of high school students in the U.S., students stated that they were motivated by learning new skills and self-improvement (mastery-oriented goals); however, teachers were more likely to think their teaching characteristics had a motivational effect on students' learning (Wiesman, 2012). Students were far more likely to attribute their motivation to desiring competency (masteryoriented), good grades (performance-oriented), and outperforming others (social goals). Teachers generally credit themselves as the most important factor in their students' performance and rank statements such as 'students are motivated when they like the teacher' very highly and rank other motivators, like good grades or competency in a skill, further down in importance.

But students do not credit teachers with such importance; the only teacherspecific variable which students have consistently found important is 'having good rapport' (Wiesman, 2012). Students believed their motivation was dependent upon intrinsic factors and self-efficacy, whereas teachers believed extrinsic variables to be of the utmost importance, usually to please parents or to receive verbal praise or some kind of reward, such as candy, from the teacher. Teachers are more likely to attribute their characteristics to student motivation, such as when they are caring, show enthusiasm, and take a personal interest in their studies, or to their instructional methodologies, such as using real-life problems in the classroom, incorporating technology into the classroom, or incorporating hands-on activities.

A study on North American university students found that students were far more likely to attribute their motivation to factors beyond the teacher's control (Gorham and Millette, 1997). This includes their credit or grade orientation (performance-oriented) and their desire to please others, especially their parents (extrinsically motivated). Teachers, on the other hand, were far more likely to attribute their students' motivation to factors within their control, such as the degree to which students complied with their requests and the way the teacher communicated those requests, like through homework assignments and in-class work (teacher characteristics) and praise given for successful completion of those requests (extrinsic rewards). Teachers also afforded significance to their selections of course assignments (teacher methodologies). 
And yet, 'teacher characteristics' only seemed an important variable when the teacher's behaviour was deemed sufficiently offensive, such as in poor presentation and lack of enthusiasm, or a disorganised and incoherent syllabus. In such instances, students report positive demotivation. Overall, teachers believed 'teacher characteristics' were the most important motivational construct (30\%), followed by goal motivation theory $(23 \%)$ and intrinsic motivation $(22 \%)$. However, students believed the top three important motivational constructs to be goal motivation (44\%), intrinsic motivation (27\%), and instructional methodologies (9\%).

A study in a Colorado high school examined student motivation and found that intrinsic motivation was the most important factor cited by students, with $96 \%$ of respondents indicating that they were most likely to be motivated when they were interested in the subject. Student participants also reported the importance of humour (88\%), teacher enthusiasm (80\%), and when they liked the teacher (79\%) (Colorado School to Career Partnership, 1999). This study complements other studies examining this age group which found that student motivation is highest when content is meaningful, relevant, and enjoyable (Thompson and Thornton, 2002). It is possible that performance-oriented goals are also closely related to intrinsic motivation goals (Linnenbrink \& Pintrich, 2002) and that students rank both performance and mastery as important variables (Dweck, 1986).

Elementary school teachers also believe that choice and inclusion are more important for student motivation than any extrinsic reward. Academics have long criticised the use of extrinsic rewards to maintain focus on a task, as supported by the literature in which two-thirds of teachers believe such approaches to be either neutral or unhelpful (Nolen and Nicholls, 1994). It is now thought that rewards should be task-dependent and used to create interpersonal relationships between the student and teacher in a non-domineering (Ryan et al., 1983) and noncompetitive classroom environment (Shindler, 2009).

Motivation decreasing from the elementary to high school level could be affected by hormonal and chemical changes in the adolescent brain, with adolescents hypersensitive to peer perception and more vulnerable to depression (social goals) (Burns and Darling, 2002). Although other research focuses on the 'self-efficacy' module, this study seeks to establish the means through which student self-assessment and self-worth are induced positively and negatively, including factors such as teaching characteristics and classroom environment (Ames et al., 1977).

\section{RESEARCH METHOD}

This research was inspired by a previous study on student/teacher perceptions of student motivation (Wiesman, 2007) and uses a similar methodological approach. This approach involves sections of three surveys, the Inventory of School Motivation (ISM) (McInerney and Sinclair, 1988), the Colorado High School Senior Survey and the Patterns of Adaptive Learning Scales (PALS) (Midgley et al., 2000). Questions from the ISM examine the intrinsic and extrinsic motivation variables, as well as performance, mastery, and social goals variables. Questions from PALS measure self-efficacy, whereas 
questions taken from the Colorado High School Survey measure teacher characteristics and instructional methodologies. The model study has shown that this approach is a reliable method by which to test student and teacher perceptions of student motivation.

The survey used in this study comprises three main sections. The first gathers information on the students and teacher: teacher age, years of experience, and sex, and student major, age, and sex. The second section of the survey contains most of the salient questions with regards to the main research question. This consists of 48 questions for both student and teacher, using a Lineart Scale, with participant responses having the choice of 'strongly agree', 'agree', 'neither agree nor disagree', 'disagree,' 'strongly disagree', and 'don't know'. The questions in the student survey focus on what the students believe motivates them, whereas the teacher survey is worded to reflect what teachers believe motivates their students. The final aspect of the survey is an open-ended question as to what students and teachers believe motivates students to learn.

The survey was conducted in order to gather student opinion on what motivates students to learn in the ESL classroom. The survey was conducted under supervision of the researcher, with all students given as much time as they needed to complete the survey. The researcher was on standby should any student have needed assistance. Independent sample t-tests were used to test for differences in means between each group, both of which were assumed to be normally distributed.

Ethical consent for this research was collected by the researcher, who attained the express permission of the Head of Foreign Faculty, as well as all students and teachers who completed the survey. Each survey took approximately 10 minutes and took place during class. Participation in the study was voluntary for students and teachers, and those students and teachers who did not sign the consent form were not included in the study. All informed consent forms gathered during the study were secured in a locked safe off premises and, on completion of the study, were destroyed. All files relevant to the study were secured in a password-protected zip file, all of which were deleted on completion of the project. The project was submitted for ethical approval and approved on 19 June 2017.

The study was limited to the data collectable by the Lineart six-point scale. This study assumes that all respondents had a working understanding of the questions posed. It further assumes that respondents were honest in their responses and that the methodology and analysis used were appropriate for the research questions under observation. The researcher made every effort to conduct the study in a fair, ethical, and objective manner.

\section{FINDINGS AND DISCUSSION}

The demographic data collected from this study includes age and gender of students and teachers, and years of teaching experience and nationality of teachers. Twenty-two teachers completed the survey, of which $73 \%$ were male and $27 \%$ female. Fifty-five per cent of teachers identified as American citizens, $14 \%$ as British, and $9 \%$ as New Zealanders, with one teacher from Ireland, 
Australia, South Africa, and Canada. The majority of teachers (55\%) had 1-4 years of university teaching experience, teaching English as a second language. Twenty-seven per cent of teachers had 5-8 years of experience, whereas $18 \%$ of teachers had nine years of teaching experience or more, with a median of four years of teaching experience. Nine per cent of teachers were between the ages of 25 and $32,59 \%$ between 33 and 39, 14\% between 40 and 47 , and $18 \% 48$ years or older, with teachers having a median age of 36 years old.

All 93 students (100\%) reported Korean nationality, of which 56\% were female and $44 \%$ male. The median age was 21 , with $9 \%$ of students $18-19$ years old, 48\% 20-21 years old, 29\% 22-23 years old, and 14\% 24 years old or older. These ages, however, were recorded according to the Korean age system, in which one is considered one year old on the day of birth and becomes another year older on New Year's Day, whereas the teachers were not recorded based on this system. For the following research questions, Levene's test for equality of variances is used to determine whether the null hypothesis - that 'the variances of the two groups are approximately equal' - is true or, otherwise, whether the alternative hypothesis is true - that 'the two different distributions have a fundamentally different shape'.

There were important differences in what kinds of methodologies students and teachers thought were most important. Teachers believed in the efficacy of encouraging students' thinking and solving real-life problems, whereas students stated the importance of quizzes, videos, magazines, and PowerPoints being used in class. This could occur due to a mismatch in the degrees of comfort and knowledge each demographic has with media. The students and teachers in the study have a mean difference in age of 16 years, with many teachers uncomfortable and unfamiliar with online technologies and, although seeing the benefits of varied multimedia use in the classroom (Kazemi and Narafshan, 2014), are unable to effectively incorporate this into the curriculum and align them with learning goals in ESL university programs (Solanki and Shyamlee, 2012). Previous studies have shown teachers to favour the promotion of creative thinking (Gorham and Millette, 1997), whereas iGen/GenZ students, born in 2000 or thereafter, a new generation of highly tech-savvy 'digital natives', are more comfortable with technology usage and exposure to digital media (Kennedy et al., 2008) and prefer a multitude of learning styles (Lujan \& DiCarlo, 2006).

It is also possible that this difference results from unaligned motives and learning goals. An analysis of Korean university students studying English in Toronto found that students were more highly motivated when their motive to learn English was well-aligned with the learning goals. While many students in Korea wish to learn English as a means to an end (e.g., making friends, living abroad) (Kim, 2009), it has been suggested that the highly competitive Korean educational system focuses on rigorous testing and traditional methods of grammar correction, for example, rather than focusing on the process, such as in English L2 writing classes (Tyson, 1997) or the testing of communicative skills. The importance that students put on using activities and various media in class may be representative of an adverse reaction to the formulaic, grammar-focused, writing and reading skills-based approach of the Korean education system, whose endemic Confucian values systematically prioritise test results over - less 
assessed - communicative skills (Choi, 2008): skills thought to align more closely with students' motives in studying English in the first place.

Previous key university studies found that personal interest in the subject and the desire to earn a good grade were perceived by both students and teachers alike to be the most important motivators (Gorham and Millette, 1997). Here, however, there is a significant difference between the teachers' view that students' interest in the subject is fundamental and students themselves who placed significant value across a whole host of different constructs. There was, therefore, very high misalignment between teacher-student motivation statements. Students strongly believed in 26 separate statements at a level of statistical significance across all constructs. Teachers subscribed to four statements at a level of statistical significance. Those statements pertain to the instructional methodology construct: 'classes should help students solve real-life problems', 'the teacher should encourage students' thinking', one statement pertaining to social goals - 'students often help friends with their work', and one statement relating to teacher characteristics - 'students are motivated when the teacher takes a personal interest in them'. Such a large variance in the subscription to statements pertaining to certain constructs is unusual and calls for further study.

Interestingly, however, 'teacher characteristics' is the only construct where teacher strength of belief has more statistically significant differences in perception statements. This is something which is in alignment with previous university studies (Gorham and Millette, 1997) which have shown that teachers consistently believe students would be more motivated than they actually are by teachers taking a personal interest in the student, showing enthusiasm for the subject, or showing concern for students' education. This study also agrees with the findings of the model study of high school students in the U.S., that students were motivated by learning new skills and self-improvement (mastery-oriented goals) and that teachers were more likely to think their teaching characteristics had a motivational effect on students' learning (Wiesman, 2007).

Korean studies have found that Korean university students are highly motivated to improve their speaking skills but do not enjoy speaking itself. Students with the highest self-efficacy are those who have spent time overseas, and Korean students typically have low self-efficacy and a fear of failure in a system which prioritises high grades (performance) over mastery (goal theory) (Truitt, 1995). Students are more motivated when they are deemed to be partaking in important work (Pintrich \& Degroot, 1990), but some students do not deem learning English to be of high importance and state themselves to be unmotivated. This chimes with what the teachers in this study report: that some students come to class unmotivated and remain so.

It is possible, however, that the students' report of teacher characteristics and methodologies being foremost in importance represents comfortability rather than a properly stated and believed principle of consideration, and the self-report nature of the study is one of its limitations. Given that this contradicts previous ESL studies, albeit, in a non-Korean specific context, re-testability of the prominence given by students to this construct is salient to determine students' self-report of teaching characteristics and methodologies and their impact on

Vol 2, No. 1, 2020 
student motivation. Social goals and self-efficacy were two motivational constructs which teachers and students both agreed were the least consequential on student motivation, as seen in previous studies (Linnenbrink and Pintrich, 2002).

\section{Goal orientation}

The first research question analyses the degree to which teachers and students differ with regards to student motivation. The goal orientation achievement theory is comprised of two constructs, performance-oriented goals and mastery-oriented goals. The researcher used an independent samples t-test to compare the mean differences of students and teachers for how their perceptions differ with regards to mastery-oriented goals' effects on student motivation. Previous studies (Wiesman, 2007; Gorham and Millette, 1997) at the university and high school level suggest students' goal orientation attributions to be stronger than that of the teachers. Students believe they are more mastery-oriented, performance-oriented, and social goals-oriented.

\section{Mastery-oriented}

Table 1. shows statistically significant differences for four of the six motivational goals with one of the six motivational goals resting on the cusp of statistical significance, and one of the six not statistically significant. In each case, student means were higher than the means of the teachers, which suggests that students believe the importance of motivational goals to be higher than that of the teachers. The model study found that learning new skills and self-improvement (mastery-oriented goals) were important to students, which agrees with statistically significant student attributions in this study's mastery-oriented construct, for example, that 'students love learning new skills' and that 'getting good at a task is very important for students'. The degree of agreement across a diverse range of large-scale studies suggests that teacher and student masteryoriented constructs differ tangibly in a consistent and statistically notable manner, across cultures and age groups.

Table 1. Results of the six mastery-oriented statements.

\begin{tabular}{llrrrc}
\hline Variable & Group & Mean & Std. Deviation & Std. Error Mean & P-Value \\
Students study hard to learn & Teacher & 3.27 & .935 & .199 & 0.78 \\
new things. & Student & 4.17 & .746 & .077 & \\
Students love learning new & Teacher & 3.64 & .658 & .140 & 0.00 \\
skills. & Student & 4.03 & .667 & .069 & \\
When students' work & Teacher & 3.45 & .963 & .205 & 0.00 \\
improves, they work harder. & Student & 4.15 & .736 & .076 & \\
Getting good at a task is & Teacher & 3.09 & 1.411 & .301 & 0.059 \\
very important for students. & Student & 4.20 & .700 & .073 & \\
Students are self-motivated. & Teacher & 3.50 & .598 & .127 & 0.00 \\
& Student & 4.27 & .678 & .070 & \\
Students want to learn to & Teacher & 3.41 & 1.368 & .292 & 0.049 \\
feel more confident in their & Student & 3.92 & .824 & .085 & \\
work. & & & & & \\
\hline
\end{tabular}




\section{Performance-oriented}

Students and teachers also answered questions relating to their perceptions of student motivation with regards to the performance-oriented motivational construct. Four out of the six motivational constructs proved statistically significant, whereas two out of the six motivational constructs were not statistically significant. Like with the mastery-oriented goals, students again had a higher means for each question, indicating that, in comparison with the teachers, these aspects of goal orientation were more important. North American university students made attributions of grade-related performance and credit-related performance to be of significantly more motivational power than teachers did (Gorham and Millette, 1997), very much agreeing with statistically significant attributions collected in this study, that 'getting performance certificates makes students work harder' and 'other people telling students what they did well is important to them'. Student and teacher attributions of student motivation have, therefore, been shown to differ meaningfully in the performance-oriented construct.

Table 2. Results of the six performance-oriented statements.

\begin{tabular}{|c|c|c|c|c|c|}
\hline \multirow{3}{*}{$\begin{array}{l}\text { Variable } \\
\text { Other people telling students what they } \\
\text { did well is important to them. }\end{array}$} & Group & Mean & Std. Deviation & Std. Error Mean & Sig. (2-tailed) \\
\hline & Teacher & 2.82 & 1.622 & .346 & \multirow[b]{2}{*}{0.00} \\
\hline & Student & 4.25 & .702 & .073 & \\
\hline \multirow{2}{*}{$\begin{array}{l}\text { Students like their work to be compared } \\
\text { to that of others. }\end{array}$} & Teacher & 2.41 & .908 & .194 & \multirow[b]{2}{*}{0.13} \\
\hline & Student & 3.88 & .778 & .081 & \\
\hline \multirow{2}{*}{$\begin{array}{l}\text { Students work best when they want to } \\
\text { feel important in front of their } \\
\text { classmates. }\end{array}$} & Teacher & 2.32 & 1.359 & 290 & \multirow[b]{2}{*}{0.00} \\
\hline & Student & 3.55 & .984 & .102 & \\
\hline \multirow{2}{*}{$\begin{array}{l}\text { Getting performance certificates makes } \\
\text { students work harder. }\end{array}$} & Teacher & 2.09 & 1.411 & .301 & \multirow[b]{2}{*}{0.00} \\
\hline & Student & 3.91 & .775 & .080 & \\
\hline \multirow{2}{*}{$\begin{array}{l}\text { Doing better than their classmates } \\
\text { motivates students. }\end{array}$} & Teacher & 3.45 & 1.405 & .300 & \multirow[b]{2}{*}{0.00} \\
\hline & Student & 3.89 & .853 & .088 & \\
\hline \multirow[t]{2}{*}{ Students need to beat their classmates. } & Teacher & 3.09 & 1.109 & .236 & \multirow[b]{2}{*}{0.24} \\
\hline & Student & 3.75 & .855 & .089 & \\
\hline
\end{tabular}

\section{Social goals}

The next research question concerns how much students and teachers differed in their perceptions of social goals' affect on student motivation. There was a significant disagreement in the degree to which perceptions of teachers and students aligned in four of the other six statements and two which were not statistically significant. Of the statistically significant statements, students again believed themselves to be more motivated by statements such as 'students are unhappy if falling behind with their work and that 'students help their classmates who are falling behind with work'. The fact that students elevate social goals attributions above that of teachers in previous research studies supports this finding, although the emphasis was on 'outperforming' fellow classmates in social goals construct statements in past studies (Wiesman, 2007). The degree to which 
students are motivated by the desire to assist their classmates, instead of the motivation to outcompete them, is an important distinction between the social goals construct requiring further study. To the extent, however, to which both types of statements are social goals attributions, the two studies are in agreement with their findings. In one respect, though, there is disagreement between this research and the model study: it was found that teachers more strongly attribute the variable 'students often help friends with their work' than students do, to a statistically significant degree. It is not clear why a statistically significant relationship would be found in the opposite direction for this particular variable, given that students made much stronger attributions for social goals constructs than teachers did. Why would students say they are motivated to 'help fellow students with their coursework' and 'help their fellow students get a good grade' but not 'help students with their work' in general? Nothing in the literature is best able to interpret this discrepancy, and so it would be best left open to repeatability studies to develop this.

Table 3. Results of the six social goals statements.

\begin{tabular}{|c|c|c|c|c|c|}
\hline Variable & Group & Mean & Std. Deviation & Std. Error Mean & P-value \\
\hline \multirow{2}{*}{$\begin{array}{l}\text { Students often help friends } \\
\text { with their work. }\end{array}$} & Teacher & 4.09 & .526 & .112 & \multirow[b]{2}{*}{0.00} \\
\hline & Student & 4.02 & .707 & .073 & \\
\hline \multirow{2}{*}{$\begin{array}{l}\text { Students are unhappy if } \\
\text { friends are failing. }\end{array}$} & Teacher & 2.50 & 1.371 & .292 & \multirow[b]{2}{*}{0.0} \\
\hline & Student & 3.99 & .651 & .068 & \\
\hline \multirow{2}{*}{$\begin{array}{l}\text { Students enjoy helping } \\
\text { classmates with their } \\
\text { coursework. }\end{array}$} & Teacher & 2.77 & 1.412 & .301 & \multirow[b]{2}{*}{0.04} \\
\hline & Student & 4.08 & .837 & .087 & \\
\hline \multirow{2}{*}{$\begin{array}{l}\text { Helping other students get } \\
\text { a good grade is important. }\end{array}$} & Teacher & 2.00 & 1.195 & .255 & \multirow[b]{2}{*}{0.586} \\
\hline & Student & 4.02 & .751 & .078 & \\
\hline \multirow{2}{*}{$\begin{array}{l}\text { Students care about other } \\
\text { people at school. }\end{array}$} & Teacher & 3.32 & .894 & .191 & \multirow[b]{2}{*}{0.88} \\
\hline & Student & 4.00 & .752 & .078 & \\
\hline \multirow{2}{*}{$\begin{array}{l}\text { Students like to help other } \\
\text { students do well at school. }\end{array}$} & Teacher & 3.45 & .800 & .171 & \multirow[b]{2}{*}{0.02} \\
\hline & Student & 3.84 & .838 & .087 & \\
\hline
\end{tabular}

\section{Intrinsic motivation}

The next research questions ask 'to what degree do teachers and students differ in their perceptions that students are intrinsically motivated to learn?' Of the six questions posed to students and teachers, five had statistically significant effects, with only one showing no statistically significant effect. Previous research in this area suggests that this construct is consistently ranked among the most important construct, $27 \%$ of students finding it the most important construct among university students versus $22 \%$ of students (Gorham and Millette, 1997), and given that performance goals are closely related to intrinsic motivation (Linnenbrink \& Pintrich, 2002), one would expect these two constructs to bear similar outcomes (students making significantly stronger attributions than teachers), as seen in this study as well as the aforementioned studies. 
Table 4. Results of the six intrinsic motivation statements.

\begin{tabular}{|c|c|c|c|c|c|}
\hline Variable & Group & Mean & Std. Deviation & Std. Error Mean & P-value \\
\hline \multirow{2}{*}{$\begin{array}{l}\text { Students work well at school } \\
\text { to show they can do it. }\end{array}$} & Teacher & 3.18 & .958 & .204 & \multirow[t]{2}{*}{0.000} \\
\hline & Student & 3.95 & .864 & .090 & \\
\hline \multirow{2}{*}{$\begin{array}{l}\text { Students like to see that they } \\
\text { are improving. }\end{array}$} & Teacher & 4.05 & 1.090 & .232 & \multirow[t]{2}{*}{0.647} \\
\hline & Student & 3.95 & .864 & .090 & \\
\hline \multirow{2}{*}{$\begin{array}{l}\text { Students enjoy a new } \\
\text { challenge. }\end{array}$} & Teacher & 3.32 & .716 & .153 & \multirow[t]{2}{*}{0.000} \\
\hline & Student & 4.23 & .662 & .069 & \\
\hline \multirow{2}{*}{$\begin{array}{l}\text { The harder the problem, the } \\
\text { harder students try. }\end{array}$} & Teacher & 2.77 & .813 & .173 & \multirow[t]{2}{*}{0.000} \\
\hline & Student & 3.90 & .795 & .082 & \\
\hline \multirow{2}{*}{$\begin{array}{l}\text { Students always try to do } \\
\text { better in their work. }\end{array}$} & Teacher & 3.45 & .596 & .127 & \multirow[t]{2}{*}{0.029} \\
\hline & Student & 3.89 & .878 & .091 & \\
\hline $\begin{array}{l}\text { Students don't need anyone to } \\
\text { tell them to work harder; they } \\
\text { do it themselves. }\end{array}$ & Teacher & 2.91 & .868 & .185 & 0.000 \\
\hline
\end{tabular}

\section{Extrinsic motivation}

Of the six questions relating to the extrinsic motivation construct, only four were statistically significant. Students were more likely to believe that they do well in order to please their parents than teachers, with a large difference between the means, suggesting a large difference in these beliefs. They were also more likely to believe that praise from their friends is important, and they like their work to be compared to their friends'.

As noted in the literature review, students generally attribute their motivation to factors outside of the teacher's control, whereas teachers usually attribute a student's motivation as a consequence of factors the teacher controls, most notably - within the extrinsic motivation construct - praise from the teacher. The results from this study, however, are in disagreement with the model study. Here, students once again much more strongly believe in the motivation deriving from factors both from within and outside of a teacher's control. One could speculate a lack of a clear delineation in this regard to be a product of the different type of relationship between Korean students and their teacher in the high school context versus their professors in the university context, or perhaps some other factor is responsible for this result.

Table 5. Results of the six extrinsic motivation statements.

\begin{tabular}{|c|c|c|c|c|c|}
\hline \multirow[t]{2}{*}{ Variable } & \multirow[b]{2}{*}{ Group } & \multirow[b]{2}{*}{ Mean } & \multicolumn{3}{|c|}{ Std. Error } \\
\hline & & & Std. Deviation & Mean & Sig. (2-tailed) \\
\hline \multirow{2}{*}{$\begin{array}{l}\text { Students like to do well } \\
\text { to please their teacher. }\end{array}$} & Teacher & 3.05 & 1.253 & .267 & \multirow{2}{*}{0.04} \\
\hline & Student & 3.49 & 1.017 & .106 & \\
\hline \multirow{2}{*}{$\begin{array}{l}\text { Students like to do well } \\
\text { to please their parents. }\end{array}$} & Teacher & 2.73 & 1.882 & .401 & \multirow[t]{2}{*}{0.04} \\
\hline & Student & 4.05 & .771 & .080 & \\
\hline \multirow{2}{*}{$\begin{array}{l}\text { Praise from students' } \\
\text { friends is very important. }\end{array}$} & Teacher & 2.68 & 1.585 & .338 & \multirow[t]{2}{*}{0.00} \\
\hline & Student & 4.22 & .764 & .079 & \\
\hline
\end{tabular}




\begin{tabular}{|c|c|c|c|c|c|}
\hline \multirow{2}{*}{$\begin{array}{l}\text { Students work best when } \\
\text { they are praised. }\end{array}$} & Teacher & 3.59 & 1.054 & .225 & \multirow[t]{2}{*}{0.23} \\
\hline & Student & 4.06 & .818 & .085 & \\
\hline \multirow{2}{*}{$\begin{array}{l}\text { Students like their work } \\
\text { to be compared to other } \\
\text { students'. }\end{array}$} & Teacher & 2.45 & .671 & .143 & \multirow[t]{2}{*}{0.00} \\
\hline & Student & 4.18 & .765 & .079 & \\
\hline \multirow{2}{*}{$\begin{array}{l}\text { Getting rewards and } \\
\text { prizes would make } \\
\text { students work harder. }\end{array}$} & Teacher & 2.86 & 1.356 & 289 & \multirow[t]{2}{*}{0.12} \\
\hline & Student & 3.49 & .963 & .100 & \\
\hline
\end{tabular}

\section{Self-efficacy}

Students and teachers reported their perceptions of self-efficacy on student motivation. Four of six questions were statistically significant, with one on the cusp of statistical significance and one question not statistically significant. Students once again held stronger beliefs than their teachers in this construct: their beliefs corresponded more strongly to statements such as they 'succeed at whatever they do', 'are very confident at school', and 'pleased with their school performance'. They also believed that 'even if the work is difficult, they can still succeed'. Student motivation and student self-efficacy is known to drop through elementary and middle school years and thereafter, due to changes associated with puberty, and pick up sometime before university to the extent that students present with much higher self-efficacy scores. Korea's culture of modesty does not seem to have presented in low self-efficacy scores, though in agreement with the Western literature more generally.

Table 6. Results of the six self-efficacy statements.

\begin{tabular}{|c|c|c|c|c|c|}
\hline Variable & Group & Mean & $\begin{array}{c}\text { Std. } \\
\text { Deviation }\end{array}$ & $\begin{array}{l}\text { Std. Error } \\
\text { Mean }\end{array}$ & Sig. (2-tailed) \\
\hline \multirow{2}{*}{$\begin{array}{l}\text { Students succeed at } \\
\text { whatever they do. }\end{array}$} & Teacher & 2.32 & .945 & .202 & \\
\hline & Student & 4.27 & .911 & .094 & 0.000 \\
\hline \multirow{2}{*}{$\begin{array}{l}\text { Students are very } \\
\text { confident at school. }\end{array}$} & Teacher & 2.82 & .907 & .193 & \\
\hline & Student & 3.87 & 1.013 & .105 & 0.000 \\
\hline \multirow{2}{*}{$\begin{array}{l}\text { Students are pleased with } \\
\text { their performance at } \\
\text { school. }\end{array}$} & Teacher & 2.59 & 1.563 & .333 & \\
\hline & Student & 3.68 & .836 & .087 & 0.004 \\
\hline \multirow{2}{*}{$\begin{array}{l}\text { Students can do almost } \\
\text { all the work if they do not } \\
\text { give up. }\end{array}$} & Teacher & 3.95 & .785 & .167 & \\
\hline & Student & 3.83 & 1.017 & .106 & 0.586 \\
\hline \multirow{2}{*}{$\begin{array}{l}\text { Students can do very hard } \\
\text { work if they try hard. }\end{array}$} & Teacher & 3.82 & .795 & .169 & \\
\hline & Student & 4.13 & .755 & .078 & 0.088 \\
\hline \multirow{2}{*}{$\begin{array}{l}\text { Even if the work is } \\
\text { difficult, students can } \\
\text { learn it. }\end{array}$} & Teacher & 3.50 & .913 & .195 & \\
\hline & Student & 4.10 & .753 & .078 & 0.008 \\
\hline
\end{tabular}

\section{Instructional methodologies}

The next research question asks to what extent teachers and students differ in their perceptions of certain instructional methodologies on student motivation. Half were statistically significant, one marginally so, and two questions had no statistically significant differences. Students strongly believed that teachers should give regular quizzes and that multimedia should be used in class as motivational 
methodologies, statements which they believed more strongly than teachers did. This result is not entirely surprising. Students ranked this construct to be in the top three most important motivational constructs in the model study, behind goal motivation (44\%) and intrinsic motivation (27\%) but receiving only $9 \%$ of the total score. Students desire for quizzes, videos, and multimedia type activities and assessments might be explained by the consideration on their behalf of 'ESL' type classes being meant to be 'fun', dynamic, and enjoyable - a marked break from their regular native instruction.

This was one of the constructs in which teachers asserted stronger attributions than students to a degree that was statistically significant. The statement that 'teachers should encourage students' thinking' $($ mean $=4.77)$ did not contradict the model study, however. Teachers believed that part of their role as educators is to equip students' thinking for 'real-world problems' (Wiesman, 2007), and as such, this statement might, in the eyes of the teacher, correspond to preparing their students' readiness for the real sworld.

Table 7. Results of the six 'instructional methodologies' statements.

\begin{tabular}{|c|c|c|c|c|c|}
\hline Variable & Group & Mean & Std. Deviation & Std. Error Mean & Sig. (2-tailed) \\
\hline \multirow{2}{*}{$\begin{array}{l}\text { Videos, magazines, } \\
\text { newspapers, and PPT's } \\
\text { should be used in class. }\end{array}$} & Teacher & 3.86 & .834 & .178 & \\
\hline & Student & 4.25 & .637 & .066 & 0.019 \\
\hline \multirow{2}{*}{$\begin{array}{l}\text { The teacher should give } \\
\text { regular quizzes. }\end{array}$} & Teacher & 3.18 & 1.053 & .224 & \\
\hline & Student & 4.22 & .778 & .081 & 0.00 \\
\hline \multirow{2}{*}{$\begin{array}{l}\text { Classes should help } \\
\text { students solve real-life } \\
\text { problems. }\end{array}$} & Teacher & 4.32 & .716 & .153 & \\
\hline & Student & 3.96 & .820 & .085 & 0.060 \\
\hline \multirow{2}{*}{$\begin{array}{l}\text { The teacher should } \\
\text { encourage students' } \\
\text { thinking. }\end{array}$} & Teacher & 4.77 & .429 & .091 & \\
\hline & Student & 3.95 & .799 & .083 & 0.00 \\
\hline \multirow{2}{*}{$\begin{array}{l}\text { Students think everyone } \\
\text { should help each other in } \\
\text { class. }\end{array}$} & Teacher & 4.50 & .598 & .127 & \\
\hline & Student & 4.30 & .818 & .085 & 0.285 \\
\hline \multirow{2}{*}{$\begin{array}{l}\text { The teacher should use } \\
\text { games, group activities, } \\
\text { and puzzles in class. }\end{array}$} & Teacher & 4.32 & .839 & .179 & \\
\hline & Student & 4.17 & .761 & .079 & 0.429 \\
\hline
\end{tabular}

\section{Teacher characteristics}

The penultimate research question looks at whether a difference exists between teacher and student perceptions of teacher characteristics on student motivation. Only two of the statements revealed statistically significant differences. Past studies, including the model study, note that teacher characteristics are consistently stated as the most important construct by teachers, registering a high $30 \%$ of teacher attributions. For students, however, this variable is consistently thought to be of little importance, except in the instances where teacher organisation, presentation style, or syllabus is so poor that it has a positive effect on students' de-motivation. The fact that teachers, therefore, more strongly 
resonated with statements such as 'students are motivated when the teacher takes a personal interest in them' is unsurprising. What is more surprising, however, is that the only statements that recorded no statistical significance - characteristics like the teacher using humour, being smart, compassionate, or enthusiastic - were not attributed more significance by teachers over their students, and one statement - 'students are motivated when the teacher involves all students in class' - even recorded statistical significance in the opposite direction, namely, that students thought this to be the case more than teachers did.

Table 8. Results of the six 'teacher characteristics' statements.

\begin{tabular}{|c|c|c|c|c|c|}
\hline \multirow{3}{*}{$\begin{array}{l}\text { Variable } \\
\text { Students are motivated when } \\
\text { the teacher takes a personal } \\
\text { interest in them. }\end{array}$} & Group & Mean & Std. Deviation & Std. Error Mean & Sig. (2-tailed) \\
\hline & Teacher & 4.41 & .503 & .107 & \multirow[b]{2}{*}{0.000} \\
\hline & Student & 3.42 & 1.126 & .117 & \\
\hline \multirow{2}{*}{$\begin{array}{l}\text { Students are motivated when } \\
\text { their teacher is very smart. }\end{array}$} & Teacher & 4.14 & .640 & .136 & \multirow[b]{2}{*}{0.823} \\
\hline & Student & 4.10 & .767 & .080 & \\
\hline \multirow{2}{*}{$\begin{array}{l}\text { Students are motivated when } \\
\text { the teacher cares about them. }\end{array}$} & Teacher & 4.27 & .550 & .117 & \multirow[b]{2}{*}{0.278} \\
\hline & Student & 4.05 & .901 & .093 & \\
\hline \multirow{2}{*}{$\begin{array}{l}\text { Students are motivated when } \\
\text { the teacher is funny. }\end{array}$} & Teacher & 4.18 & .733 & .156 & \multirow[b]{2}{*}{0.952} \\
\hline & Student & 4.17 & .670 & .069 & \\
\hline \multirow{2}{*}{$\begin{array}{l}\text { Students are motivated when } \\
\text { the teacher is enthusiastic. }\end{array}$} & Teacher & 4.36 & .727 & .155 & \multirow[b]{2}{*}{0.666} \\
\hline & Student & 4.44 & .758 & .079 & \\
\hline \multirow{2}{*}{$\begin{array}{l}\text { Students are motivated when } \\
\text { the teacher involves all } \\
\text { students in class. }\end{array}$} & Teacher & 3.68 & 1.129 & .241 & \multirow[t]{2}{*}{0.001} \\
\hline & Student & 4.30 & .672 & .070 & \\
\hline
\end{tabular}

\section{What motivates students the most?}

Students and teachers were finally asked to elaborate on what they think motivates students the most. Sixty-five per cent of students responded $(n=60)$, and the highest response was for teacher characteristics as the most important with $27 \%$ of respondents citing something relating to this variable, including 'when the teacher is funny, smart or enthusiastic' with extrinsic motivational variables such as 'praise from the teacher' also highlighted. Teacher methodologies were also emphasised, with 'fun games' being flagged as important by many students. The next most-cited variable was 'teacher methodologies', with $20 \%$ of respondents mentioning in-class activities, such as fun games in particular as well as quizzes and videos, being the most important for motivation. Ten per cent of students listed an intrinsic motivation variable as most important, such as 'wanting to get a good job, travel, or be better at communicating'. Eight per cent of students listed an extrinsic motivation variable, such as 'teachers praise or prizes', as being the most important.

Teacher responses to these questions were more detailed and in-depth. Ninety-one per cent of teachers responded $(n=20)$. Some teachers mentioned motivational constructs, which were referred to 33 times in total. Teachers mentioned teaching characteristics and methodologies the most; in 30\% of 
responses (15\% for each, respectively), intrinsic motivation had the second most mentions in $24 \%$ of cases. In each instance, however, teachers were unanimous that only some students come to class intrinsically motivated to achieve and that many students do not. Performance orientation had the next most mentions, in $18 \%$ of cases with 'good grades' considered the most important factor. Masteryorientation had $9 \%$ of the overall importance attributions, as did extrinsic motivational factors. Self-efficacy had $6 \%$ of the mentions, and social goals just $3 \%$.

Figure 1. Per cent of students/teachers reporting a construct to be of most importance in an extended survey question.

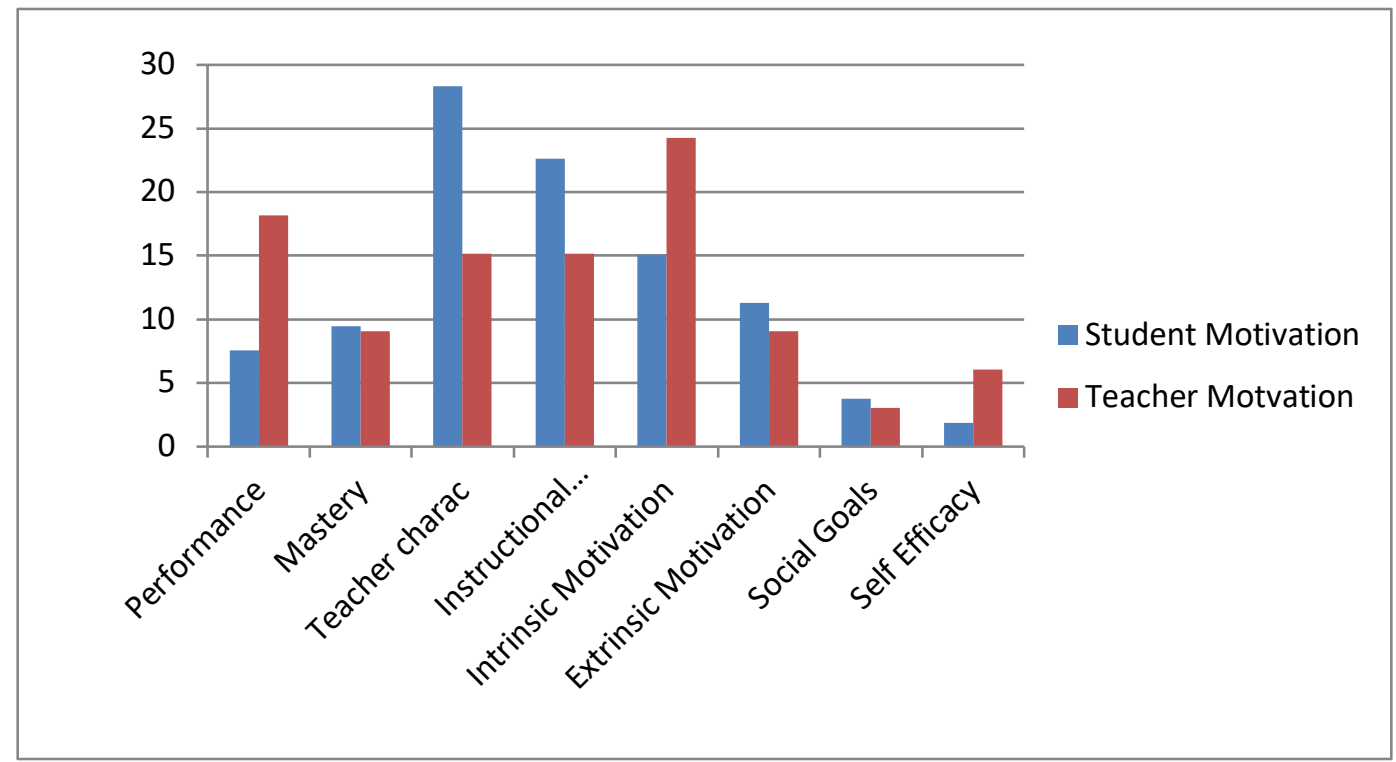

\section{CONCLUSION}

University students and teachers generally differ in what they believe are the most important motivating factors for students. Teachers believe students are most strongly influenced by intrinsic motivation factors with the caveat that some students are never intrinsically motivated, regardless. Teachers also thought students were performance motivated, specifically by getting good grades. However, students believe that teacher characteristics and instructional methodologies are more important factors. Students report stronger motivation across all motivational constructs, except for 'teacher characteristics', where teachers reported high importance in agreement with misalignment in perceptions in previous studies.

Students generally differ from teachers on the performance-oriented statements, with students more strongly believing that they are motivated by aspects such as outperforming their classmates. Students also state much stronger beliefs in social goals, believing they are likely to be motivated by helping their friends, although teachers had a slightly stronger belief than students that students often help their friends with work. 
Students' perception of student intrinsic motivation was high and statistically significant, with large differences between student and teacher. Fewer differences exist for the extrinsic motivation construct, but wherein statistically significant differences exist, it is the students who believe more strongly that they are motivated by praise from their friends and teachers. Students also believe in perceptions of their own self-efficacy as an important motivational construct, more than teachers did. The most important teaching methodologies are thought by the students to be the use of quizzes and multimedia, such as PowerPoint presentations, whereas teachers think students are most motivated by encouraging the students' thinking, influenced perhaps by the intricacies of the Korean education system and the teacher-student generational gap.

Finally, in terms of teacher characteristics, this study shows that most students believe they are motivated when the teacher involves all students, and the teachers believe students are motivated when the teacher takes a personal interest in students. This research supports the conclusions of previous research at the high school level which suggest teachers overstate the importance of teacher characteristics, but the degree of student report for the importance of teacher characteristics is not found in previous studies; goal and intrinsic motivation factors are found to be more important (Wiesman, 2007).

\section{ACKNOWLEDGEMENT}

My thanks to staff and colleagues at Soonchunhyang University, Asan, South Korea and Hanyang University, Seoul, South Korea for support with this research project. Thank you also to Dr. David Hyatt, School of Education at the University of Sheffield, and Dr. Sabine Little, School of Education at the University of Sheffield, for their support of this project.

\section{REFERENCES}

Ames, C., Ames, R., \& Felker, D. W. (1977). Effects of competitive reward structure and valence of outcome on children's achievement attributions. Journal of Educational Psychology, 69(1), 1-8.

Bandura, A. (1993). Perceived self-efficacy in cognitive development and functioning. Educational Psychologist, 28(2), 117-148.

Burns, A., \& Darling, N. (2002). Peer pressure is not peer influence. The Education Digest, 68, 4-6.

Choi, I. C. (2008). The impact of EFL testing on EFL education in Korea. Language Testing, 25(1), 39-62.

Colorado School to Career Partnership. (1999). What works? Colorado high school senior survey, initial results. Retrieved from. https://files.eric.ed.gov/fulltext/ED431887.pdf

Damron, J. C. (1995). The three faces of teaching evaluation [Unpublished online manuscript]. Douglass College, New Westminster, British Colombia.

Dweck, C. (1986). Motivational processes affecting learning. American Psychologist, 41(10), 1040-1048. 
Eccles, J., \& Wigfield, A. (2002). Motivational beliefs, values, and goals. Annual Review of Psychology, 53(1), 109-132.

Gorham, J., \& Millette, D. M. (1997). A comparative analysis of teacher and student perceptions of sources of motivation and demotivation in college classes. Communication Education, 46(4), 245-261.

Guilloteaux, M. J. (2013). Motivational strategies for the language classroom: Perceptions of Korean secondary school English teachers. Elsevier, 41(1), 3-14.

Kazemi, A., \& Narafshan, M. H. (2014). Technology and English Language Teaching (ELT). Advances in Language and Literary Studies, 5(6), 60-67.

Kemmis, S., \& Wilkinson, M. (1998). Participatory action research and the study of practice. In B. Atweh, S. Kemmis, \& P. Weeks (Eds.), Action research in practice: Partnerships for social justice in education. London: Routledge.

Kennedy, G. E., Judd, T. S., Churchward, A., Gray, K., \& Krause, K. L. (2008). First year students' experiences with technology: Are they really digital natives?. Australasian Journal of Educational Technology, 24(1), 108-122.

Kim, T. Y. (2009). The dynamics of L2 self and L2 learning motivation: A qualitative case study of Korean ESL students. English Teaching, 64(3), 49-70.

Lepper, M. R., Corpus, J. H., \& Iyengar, S. S. (2005). Intrinsic and extrinsic motivational orientations in the classroom: Age differences and academic correlates. Journal of Educational Psychology, 97(2), 184-196.

Linnenbrink, E., \& Pintrich, P. (2002). Motivation as an enabler for academic success. School Psychology Review, 31(3), 313-327.

Lowman, J. (1995). Mastering the techniques of teaching (2nd ed.). San Francisco: Jossey-Bass.

Lujan, H., \& Dicarlo, S., (2006). First-year medical students prefer multiple learning styles. Advances in physiology education. 30. 13-16.

Maslow, A. (1954). Motivation and personality. New York: Harper \& Row Publishers.

McInerney, D., \& Sinclair, K. (1992). Cross cultural model testing: Inventory of school motivation. Educational and Psychological Measurement, 51(1), 123-133.

Midgley, C., Maehr, M. L., Hruda, L. Z., Anderman, E., Anderman, L., Freeman, K. E., \& Urdan, T. (2000). Manual for the patterns of adaptive learning scales. Ann Arbor, Michigan: University of Michigan.

Nolen, S. B., \& Nicholls, J. G. (1994). A place to begin (again) in research on student motivation: Teachers' beliefs. Teaching and Teacher Education, 10(1), 57-69. 
Park, G. P., \& Lee, H. W. (2006). The characteristics of effective English teachers as perceived by high school teachers and students in Korea. Asia Pacific Education Review, 7(2): 236-248.

Pintrich, P. R., \& de Groot, E. V. (1990). Motivational and self-regulated learning components of classroom academic performance. Journal of Educational Psychology, 82(1), 33-40.

Ryan, R. M., Mims, V., \& Koestner, R. (1983). Relation of reward contingency and interpersonal context to intrinsic motivation: A review and test using cognitive evaluation theory. Journal of Personality and Social Psychology, 45(4), 736-750.

Shindler, J. (2009). Examining the use of competition in the classroom. In Transformative classroom management. Retrieved from: http://web.calstatela.edu/faculty/jshindl/cm/competition.htm

Solanki, D., \& Shyamlee, M. P. (2012). Use of technology in English language teaching and learning: An analysis. 2012 International Conference on Language, Medias and Culture IPEDR, 33, 150-156.

Thompson, B., \& Thornton, H. (2002). The transition from extrinsic to intrinsic motivation in the classroom: A first year experience. Education, 122, 785792.

Truitt, S. (1995). Beliefs about language learning: A study of Korean university students learning English. Texas Papers in Foreign Language Education, 2(1), 1-16.

Tyson, R. E. (1997). Motivation, self-confidence, and the process approach in Korean university writing classes. In 1997 National Korea TESOL Conference. Kyongju, South Korea.

Wiesman, J. (2007). A comparative analysis of teacher and student perceptions of motivation in high school classes (Doctoral dissertation). Regent University. Retrieved from ProQuest Dissertations Publishing.

Wiesman, J. (2012). Student motivation and the alignment of teacher beliefs. The Clearing House: A Journal of Educational Strategies, Issues and Ideas, 85(3), 102-108.

Wigfield, A., Eccles, J., \& Rodriguez, D. (1998). The development of children's motivation in school contexts. Review of Research in Education, 23, 73118. 